\title{
Inheriting and Promoting the Chinese National Culture and Constructing Enterprise Culture \\ Yulong $\mathrm{Tu}^{*}$
}

School of Social and Public Administration, Lingnan Normal University, Zhanjiang, Guangdong, China

DOI: $10.36347 /$ sjebm.2020.v07i07.002

| Received: 12.07.2020 | Accepted: 25.07.2020 | Published: 30.07.2020

*Corresponding author: Yulong Tu

Abstract

Review Article

The Chinese natioanal culture has been impacted by the wave of reform and opening up, but its integrity and foundation have not been shaken and breaken. The Chinese national culture still plays a positive effect for modern enterprise culture construction. In the process of globalization the enterprise's development cannot be separated from the foundation of the national culture. Enterprise need pay attention to inheriting and promoting the Chinese national culture in the enterprise culture construction, so that the Chinese excellent national culture elements can still effectively exist, only in this way can the enterprise culture increase the soft power of the enterprise, consequently promote the development of the whole national economy.

Keywords: Culture; National culture; Enterprise culture; Inherite; Promote.

Copyright @ 2020: This is an open-access article distributed under the terms of the Creative Commons Attribution license which permits unrestricted use, distribution, and reproduction in any medium for non-commercial use (NonCommercial, or CC-BY-NC) provided the original author and source are credited.

\section{INTRODUCTION}

The Chinese national culture has a long history and is famous for its five thousand years of civilization in the world. The written history of civilization has spanned more than 3,000 years, In terms of cultural form and value system, it has lasted for more than two thousand years under a closed self-perfecting system. In the historical changes of Chinese culture, the culture is constantly changing and developing. The evolution of Chinese national culture over time and in history is the result of the long-term exchanges and integration of various regions and ethnic groups. Compared with the 30 years before the reform and opening up, some values and behaviors of the Chinese people have undergone profound changes [1], but the Chinese national culture still exists vigorously. As a kind of consciousness, it is by no means passive. In fact, it is always in the process of interaction with the economy [2]. The enterprise is a cell of a country's national economy, the domestic and foreign scholar's studies have shown that the enterprise culture can affect the internal growth of the enterprise, the success of enterprise strategy and the final performance [3]. If every enterprise can operate and manage by virtue of the power of culture, not only can improve the economic efficiency of enterprises, but greatly promote the development of the whole national economy. How does an enterprise inherit and carry forward the Chinese national culture and embed it into the construction of enterprise culture? This is a practical and specific problem related to economic development, which has not only theoretical significance, but also practical value.

\section{The characteristics of Chinese national culture}

A characteristic of Chinese national culture in the Chinese nation culture is long-term dominant by Confucianism, which was initiated by Confucius in the Spring and Autumn Period, have become the mainstream of state politics and ideology for two thousand years after the Han Dynasty [4]. Although there were occasional challenges from Taoism, legalism and Buddhism, they did not pose any substantial threat to the Confucian cultural tradition. Even in the end, these thoughts were integrated and absorbed by Confucianism and directly enriched the connotation of Confucianism, thus making the Confucian tradition refreshed and transformed [5]. Therefore, it is necessary to take Confucianism as the origin and core to understand the ethical concepts and social consciousness shaped by Confucianism to explore the characteristics of Chinese national culture [6].

\section{Familism}

As many scholars have repeatedly pointed out that one of the characteristics of the Chinese national culture is familism [7]. Although the connotation of current familism has changed, it is quite resilient to the cultural ideal of the family. It is difficult to change [3]. One of the important reasons why familism has not changed is that families are dependent on each other. 
Not only do parents do their best to raise and take care of their children, but most children see filial piety as a strong duty and are willing to support and care for their parents in their old age. When a family member is in trouble and needs help, other family members are also willing to help. Hsu [13] once pointed out, the World view of Chinese people is that family ties are forever regarded as eternal. Therefore, individuals are restricted by this affection and pursue mutual dependence.

\section{Human Connection Principles}

It is helpful for an individual to maintain a harmonious interpersonal relationship with his relatives and friends by communicating with them according to traditional human connection principles. In one of the biggest characteristic of modern industrial and commercial relationships in the society, the human connections are regarded as a tool to help each other gain personal goals. In addition to associating with relatives and friends with emotional elements, instrumental relationships are also established with others other than emotional networks to obtain various social resources to meet the needs of oneself or one's family. Fei Xiaotong [14] and Jin Yaoji [15] have pointed out, Chinese society is covered by a series of invisible networks, which are intertwined into a cohesive and dynamic social structure, which makes people feel like they are in the same boat.

\section{Status of Ethical}

Ethics is the inner order of interpersonal relations in human society. The existence of the ethics is not expressly set, also do not have mandatory, which is produced by the evolution of history and culture and heritage and becomes a kind of inner conscience and external behavior criterion of binding force. The hierarchy of status derives from five basic ethical relationships, which are focus on respecting those in higher positions and making decisions by those in higher positions, Adherence to such relationships reflects the Confucian emphasis on unequal relationships between people, which expresses an emphasis on power, harmonious, stable hierarchical relationships and the fulfillment of their respective roles. This tendency is reinforced in childhood and in education.

\section{To pay Attention to the Harmony}

Paying attention to harmony is one of the basic theory of Confucianism, which forms the important value connotation of unity of the nature and the mankind. Ji Xianlin who is master of Chinese culture, once said that the unity of the nature and the mankind is the greatest contribution of Chinese culture to the world. Harmony between the nature and the mankind means peaceful coexistence, not conquering and being conquered. "The sky" represents the principle of nature, which means conformity and union. "Harmony" has the meaning of conformity and union. "Oneness" refers to the close and inseparable relationship between two opposing sides. It's ideal state is to pursue the universal harmony between the man and the society, the man and the nature. That is to advocate doing things to conform to the laws of nature, so that people and nature as one. This emphasis on harmony has deeply influenced Chinese people's behavior and way of dealing with the world [2].

\section{Inheritance of Chinese national culture and construction of enterprise culture}

An enterprise is not an isolated production unit or economic organization, let alone a simple combination of several production personnel and management personnel. The formation of enterprise culture in social groups is by no means natural, but the result of the influence and infiltration of social culture in the region where the enterprise belongs [8]. Enterprise culture is rooted in traditional culture and directly reflects the characteristics of traditional culture. The fine traditional culture of Chinese national culture gives the soil of enterprise culture and directly influences the speech, thought and behavior of enterprise employees, which is carried forward and spread for a long time with the changes of the times. The value orientation of Chinese culture affects the choice of likes and dislikes of enterprise employees, arouses people's emotional resonance, and promotes the cohesion and development power of enterprises [8]. Only by building enterprise culture in the traditional culture recognized by the whole nation can an enterprise maximize the enthusiasm, initiative and creativity of its personnel. Based on the profound cultural accumulation and historical wisdom of the Chinese nation, the enterprise culture will be built up with a cohesive mind and strength.

\section{Family doctrine and enterprise culture construction}

In the Chinese culture, familism emphasizes family interests as its ultimate goal, advocates family interests over personal interests, and individuals must unconditionally submit to family groups. An enterprise is also a big family in a specific environment. The operation of an enterprise includes not only its own behavior, but involves different stakeholders in the society. If we lose the trust and support from all walks of life, it will be difficult for enterprises to survive and develop. Inheriting the cultural tradition of familism, building the enterprise culture on the basis of "family affection", cultivating the sense of belonging and enterprise atmosphere of "enterprise like home", "sharing weal and woe". The enterprise can really care about employees from the perspective of thinking, work and life. The "familism" embedded in the enterprise provides emotional support for employees to promote the internalization of ethics and values, and then regulate the behavior of enterprise employees, which will have a strong appeal to employees and help guide the behavior and motivation of employees to the enterprise. Through training and guidance of 
employees, to reinforce their commitment on both the collectively goal and specific individually goal. When respecting the individuality and creativity of employees and recognizing the contribution of each employee, a strong magnet effect will be generated, which can not only form a strong centripetal force and cohesion, but attract all kinds of outstanding talents.

\section{Human connection law and enterprise culture construction}

Enterprise culture focuses on the enterprise values, which is the enterprises take what is regarded as the most valuable thing. More and more scholars believe that the enterprise to gain remarkable success is no longer a strict rules and regulations, the financial indicators, capital or equipment, and lies in whether the full attention of employees, whether it can fully mobilize enthusiasm and creativity of employees. The enterprise culture on the basis of inheriting and developing traditional management theory, need break through the old too much emphasis on organization system, scientific management theory and methods, ignoring irrationality and the organizational factors, especially the main body of the employees in enterprises. The enterprises need emphasize on attaches great importance to the system, organization and other hardware at the same time, need pay special attention to people's emotional factors. That means break through the enterprise boundaries, which will integrate people, enterprises and society as a union to improve the employees' job satisfaction and increase employee commitment to the organization. Employees can defend and achieve the interests and objectives of the organization before the interests of oneself or the group, and want to have the identity of its membership in order to promote the realization of corporate goals, which will promote employees' organizational citizenship behavior, such as saving initiatively the resources for the enterprise and making recommendations on the development of enterprises how to better. In the long run, these actions can improve the enterprise performance.

\section{Status Ethics and enterprise culture construction}

In our traditional culture and thought, harmony is the highest level of interpersonal relationship, and this kind of harmony is based on the status ethics of the relationship between the elders and the children and mutual obligations among people in a group. That is, the senior or high-ranking person who has the obligation to care for and protect the younger and the junior-ranking person, is manifested in the corporate culture as a paternalistic leadership style with managers exhibiting strict discipline and authority, paternal kindness and moral integrity. Authoritarianism emphasizes the absolute authority of the manager. Subordinates show unconditional obedience. Managers exercise strict control over subordinates and keep information confidential while subordinates show obedience and awe correspondingly. Kindness means that managers treat subordinates as family members that give the care and guidance on the work and life and help when subordinates are in distress. Out of respect, subordinates show obedience and loyalty. Moral emphasises the virtues of managers and role models, such as setting a good example, performing duties honestly and considering the overall [9].

\section{Harmonious thought and enterprise culture construction}

The so-called harmonious corporate culture refers to the harmonious, stable and orderly state between the internal and external elements of an enterprise, which mainly includes four levels:

- Harmonious relationship between the enterprise and employees;

- Harmony among employees;

- Harmonious relationship between the enterprise and the society;

- Harmony between the enterprises and the natural.

Enterprise as one of the most basic element of society and economy, the construction of a harmonious enterprise is an important condition to realize harmonious society. Harmonious corporate culture not only can infect people and motivate people to form a cohesive force in the enterprise, but help the enterprise establish a good image, enhance awareness of credibility and social recognition, which finally can enhance the enterprise competitiveness. Behind the sustainable development of the enterprise is the harmonious development between the enterprise and the employees, between the enterprise and the society, and between the enterprise and the nature, which is based on the harmonious culture. The harmonious culture emphasizes mutual respect, fair competition, social responsibility, ecological and environmental awareness and economy awareness. This enables the enterprise to pursue financial goals while also considering the harmonious development between the employees, the enterprise, the society and the nature. Paying attention to the indicators of economic benefit of enterprises, as well as the indicators of social benefit such as resources, environment and humanities, is conducive to the sustainable development of the enterprise.

\section{The promotion of Chinese national culture and enterprise culture construction}

In order to adapt to rapid technological change, globalization of competition and the challenge of knowledge economy, the enterprise must have the positive initiative, risk bearing and flexibility. The elements in Chinese culture that are complementary to the external environment need to be carried forward. The elements that are opposite to the external environment must be weakened or abandoned. Only by carrying forward the tradition can we not suffocate the spirit of innovation and keep pace with the times. 
To establish new rules of human relations and interpersonal interaction regulation

"Guanxi", the central concept in Chinese business, is now well known around the world. In the past, human power and money in the Chinese society are the most important social resources. If the three can strengthen each other, people can do any good [6]. As a result, people are keen to will put lots of manpower and material resources on how to get through and maintain the relationship, which leads to "functionalist" or "instrumentalist" values. What people value most is not morality, but how to use the fastest way to achieve a certain goal through human resources and other resources, which makes some styles appear without principle, and presents the situation orientation behavior. That is easy to form a personal-interest clique in the enterprise, cause internal friction and hinder the healthy competition of the enterprise. Therefore, in the context of interpersonal interaction of various instrumental relationships, the enterprise need establish a new human principle to regulate interpersonal interaction between employees. Through the establishment of a fair management system as the fundamental, emplyees can be treated similarly in the same system. Only through paying attention to the fairness and durability of the system can the enterprise stimulate the enthusiasm of employees, whcih can enhance the competitiveness of the enterprise.

\section{To weaken the sense of rank and stimulate innovation in harmony}

Harmony is the premise of the enterprise existence. The consciousness of the level of position ensures the stability of the enterprise to avoid in total chaos. But too much emphasis on the consciousness of status and hierarchy will restrict the innovation of the enterprise. Innovation is the generation of new ideas that meet expectations or respond to organizational opportunities. The successful implementation of a new idea requires the support of different roles in the organization and the mutual assistance of different members. In particular, the senior people in the enterprise directly affect the innovation development. Although the sustainability of the harmonious layout makes the enterprise have great stability, it will be difficult to change once the harmonious layout has been achieved or optimized. Managers have realized the internal danger of excessive harmonious in the dynamic environment, and the traditional idea of status ethics has been questioned. At present, managers must make the enterprise have enough creativity to guarantee competition. The enterprise need to relax control and tolerate the employees' recommendations in order to manage the change caused by all kinds of conflicts and meet the new development direction. Weakening the consciousness of the position can help the enterprise keep the certain flexibility and speed in harmony, which can make the enterprises change direction quickly in continuous innovation.
To pay attention to the national character of the enterprise culture and appreciate excellent national culture

In the 19th century, the Chinese society came into contact the West. Confucian ethics had always been regarded as the ideal ethical value system. By the end of the Qing Dynasty, China had been divided and bullied by western powers. Many advanced intellectuals with traditional Confucian education raided Confucian ethics, together with a large scale of the rupture of traditional culture after the founding of the People's Republic of China. Today, influenced by the antiConfucian thoughts, there are still those who hold the view that Confucianism as a whole is entirely feudal dross. The Chinese national culture has dross, but more essence. We must distinguish clearly. If it is completely westernized, it completely ignores the issue of national subjectivity in the modernization process of a specific enterprise that is the relationship between the specific traditional culture and the community. The internal vitality of the traditional culture is always reflected in a specific way from generation to generation [10]. Any modern culture is developed and improved by absorbing and inheriting the essence of traditional culture. There are many ideas of the Chinese national culture that can be applied to the management of the enterprise culture through refinement and transformation, such as loving peace, diligence, courage, and ceaseless self-improvement. We have reason to believe that it is in line with the requirements of the development of modern enterprises. Internalizing these excellent traditional cultures as part of the construction of the enterprise culture can become an important part of the internal driving force of the enterprise development.

\section{To contain foreign national culture and form Chinese-type enterprise culture}

People in different societies consistently differ in their basic attitudes, values, and skills, which means that each group has a different culture [16]. With the acceleration of China's opening up, both the political system and the economic system should move towards rationalization. We should not blindly follow westernization and should actively choose advanced culture from the western, transcending the domination of capitalist and socialist ideology, which can move towards a new political, economic and cultural system with Chinese characteristics. The enterprise culture is the embodiment of national culture and the result of the development of cultural communication. Although domestic and foreign scholars' researches on the enterprise culture are based on the traditional culture of their own nation, they believe that the enterprise culture cannot be copied, no matter how good the enterprise culture is. They all propose that it is necessary to learn from outside. The construction of the enterprise culture with Chinese characteristics cannot stay out of the national conditions, but must combine the Chinese national culture with the excellent foreign national 
culture, such as the group spirit of Japanese and the competition enterprise culture of the western. Under the background of globalization market environment, we should combine the excellent cultural tradition of Chinese culture with advanced foreign management ideas, emphasize the diversity and multifarious culture, highlight harmony, competition and innovation, form the enterprise culture with Chinese characteristics, which can enhance the soft power of enterprises.

To excavate the positive values in Chinese culture and set up inspiring goals and missions

The people in the pursuit of glory and dream must want to have a convincing and noble culture value system. A country that is the case, it is more so for the enterprise. The enterprise values are the fundamental view and evaluation of the enterprise's production, operation, goal pursuit and its own behavior in the process of pursuing business success. Although different enterprises have different expressions of their own value beliefs, all of them emphasize the existence value of the enterprises in social life so as to unite the enterprise and employees. The experience of successful enterprises shows that Chinese culture values are positive and upward. Such as self-discipline, diligence, frugality, family management, family affection and trust. These values should be integrated into the construction of the enterprise values, which can enable employees to maintain the interests and development of the enterprise and regard enterprise development as the most meaningful work so as to stimulate employees' great initiative and creativity in the work, meanwhile the enterprise's external adaptability and internal coordination ability can increase. That can help the enterprise achieve success and development. The sense of mission can stimulate employees' great enthusiasm and desire for innovation, generate the ability to continue, and achieve the sustainable development of the enterprise.

\section{To carry forward the spirit of patriotism and inject spiritual impetus into the enterprise culture construction}

An enterprise is a symbol to measure a country's technology, industrial base and international competitiveness. If an enterprise does not have a strong sense of national responsibility and cannot create and develop itself in the process of opening up to the outside, it will not establish its national image and enhance its international competitiveness. If the enterprise culture is built with patriotic tradition, the enterprise will have more sense of national responsibility and national consciousness, which is conducive to enhancing the enterprise's national pride and the confidence of a strong country. Only on this basis can we gradually form the value orientation of revitalizing the motherland and making active contributions. Today's international competition is no longer the competition of military strength, but the competition of economic strength and cultural soft power [11]. In this competition, as the main body of the economy, the enterprises should have a historical mission to the development of the country and the nation. Only when the enterprise is competitive can a country has the power and right of speech. To a large extent, the image of a country is built up by a group of excellent enterprises and products, especially some internationally renowned enterprises. Developing patriotism can inject strength into the enterprise culture, which can link the development of Chinese enterprises with the rejuvenation of the Chinese nation's economy and the realization of Chinese modernization [12]. Only by building up the faith of serving the country through the industry and connecting the destiny of the enterprises with that of the country and the nation can Chinese enterprises become bigger and stronger.

\section{CONCLUSION}

The inheritance and promotion of Chinese national culture

Culture is the criterion by which people measure things and behaviors. It is closely related to national characteristics, cultural environment and historical tradition. The national culture is a kind of mixed product, which continues in the process of expansion and adjustment. Today, due to the rapid development of science and technology, the world has become a global village, while economic activities have long gone beyond national boundaries. As a result, culture has become increasingly diverse. When our national culture operates in the current social environment, it may be completely integrated or cause conflicts. This depends on whether the national culture and the existing social environment are complementary or mutually exclusive. Whether it is integration or innovation, it is a new adaptation process, namely the unity and harmony between internal and external. On the one hand, we should inherit the fine traditions of Chinese culture. Sociologist Jin Yaoji said that there would be no modernization of traditions. A little analysis revealed that some elements of Chinese tradition existed powerfully in new forms. After the impact of the reform and opening up, some traditions of Chinese culture have been consciously weakened and abandoned, but they have not fundamentally shaken and broken through the whole system. On the other hand we need to carry forward our national culture. In the process of the world integration, the thoughts of any nation can no longer speak alone, and no culture can develop within its own closed system. We should put China into the process of the world modernization, and take the world as a whole to rethink the inheritance and promotion of Chinese national culture.

\section{The construction of the enterprise culture keeping pace with The Times}

The enterprise culture is a set of beliefs and assumptions developed by the enterprise to integrate the internal and adapt to the external changes. These beliefs and assumptions are followed by employees. In the long 
run, only strategies that respond to environmental change will survive and be widely emulated by other organizations. The enterprise culture changes in response to the economic, the technological, and the political environments. The enterprise culture changes shape the environment in contrast. The enterprise culture is an important part of Chinese national culture and the foundation of the enterprise development. Therefore, the construction of the enterprise culture should emphasize two aspects: on the one hand, rationally and selectively borrow and absorb the advanced management experience of the West. We should borrow whatever is conducive to the modernization of the enterprise. Anthropologists tell us that cultural borrowing is a necessary way for any culture to enrich and develop itself. The same is true for the enterprise culture construction. On the other hand, the construction of the enterprise culture should not only inherit the Chinese national culture but carry forward. "Tradition" and "modernization" are not binary opposites. The humanistic spirit, reasonable mechanism and ethical characteristics of traditional culture are still providing rich nutrition for the construction of contemporary corporate culture. At the same time, in the process of enterprise modernization, it is a kind of innovation to return the lost national culture tradition to the construction of enterprise culture, which must meet the needs of the environment of the enterprise, otherwise it is a retro rather than an innovation. In the process of drawing lessons from national culture, the construction of the enterprise culture must use and rely on modern social science, especially the behavioral science, to inherit and carry forward Chinese national culture systematically. It can be predicted that successful construction of the enterprise culture belongs to those that can draw the essence from the Chinese national culture and carry forward the Chinese national culture in the process of adapting to the environment.

\section{REFERENCES}

1. Jin B. Research on the New Normal of China's Economic Development. Chinese Industrial Economy. 2015; 1:5-18.

2. Zhang RD, Huo HX. Introduction to Corporate culture, Tianjin: Nankai University Press. 2004;11.

3. Chen CHua, Cao ZT, Zeng H. Corporate Culture, Beijing: Machinery Industry Press. 2013:11.

4. Yang GS. Chinese Values, Beijing: China Renmin University Press. 2008.

5. Guo QY. Studies of Confucian Culture. Beijing: Life. Reading. 2013: 8.

6. Yang GS, Huang GG, Yang ZF. Chinese psychology. Chongqing: Chongqing University Press. 2008.

7. Chu XP. Social relation capital and the Entrepreneurship and development of Chinese Family business. Nankai Management Review. 2003; 6:8-12.

8. Wang SJ, Liu SS. Discussion on the Evolution Mode of Chinese enterprise culture. Management World. 2013; 2:184-185.

9. Lin $\mathrm{CP}$, Zhuang BC. Influence of paternalistic leadership on management Innovation: an integrated model. Scientific research. 2014; 32(4): 622-630.

10. Li DH. Enterprise culture with Chinese Characteristics. Beijing: Economic Management Press. 2012: 5.

11. Li CY. Organizational Culture: From the perspective of organizational effectiveness. Beijing: Peking University Press. 2013:1.

12. Wang, SJ, Tu YL, Liu SS. The evolution of stateowned enterprises in South China: The choice of property right system perspective. The Anthropologist. 2014; 18(1):103-111. 